\title{
Dance and Socio-Cybernetics: \\ The Dance event of "K'na" As A Shaping Component of The Cultural Identity Amongst the Arvanites of Neo Cheimonio Evros, Greece ${ }^{1}$
}

\author{
Eleni Filippidou ${ }^{2}$ and Maria Koutsouba \\ National and Kapodistrian University of Athens, Greece
}

\begin{abstract}
The research field of this paper is the wedding dance event of "K'na", as this takes place by the Arvanites of Greek Thrace, an ethnic group moved to the area from Turkish Thrace in 1923. The aim of this paper is to investigate whether the three components of dance, music and song of Greek traditional dance, as these reflected in the " $\mathrm{K}$ 'na" dance event amongst the Arvanites ethnic group of Neo Cheimonio (Evros), are related to issues of ethno-cultural identity under the lens of socio-cybernetics. Data was gathered through ethnographic method as this is applied to the study of dance, while its interpretation was based on socio-cybernetics according to Burke's identity control theory. From the data analysis, it is showed that through the "K'na" dance event the Thracian Arvanites of Neo Cheimonio shape and reshape their ethnocultural identity as a reaction to the input they receive from their environment. Therefore, the "construction" of their identity, as a constant process of self-regulation and internal control, is subjected to the conditions of a cybernetic process.
\end{abstract}

Keywords: dance ethnography, ethnic group, identity control theory, refugees, Thrace.

\section{Introduction}

Identity is a concept that has come to the fore in recent years, as it has attracted the interest of many scholars. Scholars, such as anthropologists, sociologists, socio-linguists, and folklorists, have been focusing on identity issues since the early 1980s, when the current of multiculturalism in North America was observed. During the same period, ethnographic studies appeared to negotiate the relationship between culture and politics and refer to issues of cultural identities, ethnic identities, national identities, etc. In particular, some anthropologists and sociologists in their studies deal with issues concerning the national and cultural border. Indicatively, Barth (1969),

\footnotetext{
${ }^{1}$ This research is co-financed by Greece and the European Union (European Social Fund-ESF) through the Operational Programme «Human Resources Development, Education and Lifelong Learning» in the context of the project "Reinforcement of Postoctoral Researchers - 2nd Cycle" (MIS-5033021)", implemented by the State Scholarship Foundation (IKY).

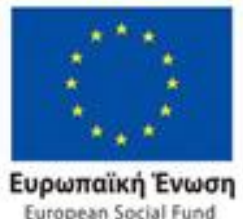

Operational Programme Human Resources Development, Education and Lifelong Learning

Co-financed by Greece and the European Union
} 
Cohen (1994) and Fischer (1986) and Beckett and Kobayashi (2020) mentioned, while other researchers, such as Handler and Linnekin (1984) and Hanson (1989), engage in the study of ethnicity and the formation of the identity of individuals and local groups or ethnic groups. There is also a third category of researchers, anthropologists, sociologists, social anthropologists, historians and researchers in political science, such as Anderson (1991), Gellner (1983), Hobsbawn (1994), Jenkins (1997), Smith (1986) and Tonkin, McDonald and Chapman (1989), who discuss issues of ethnicity, national identity and nationalism as opposed to the creation of "nation-states" in various parts of the world.

As far as Greece is concerned, in the last two decades, there has been a growing interest in studying issues related to national and ethnic identities. A number of Greek scholars have dealt with issues related to nationalism and tradition, the ambiguities of nationalism, national and cultural minorities, the concepts of "identity" and "otherness", nationalism and the "politicization of culture" (Robbins et al. 2019). Indicatively, Avdela (1995), Demertzis (1996), Kitromilides (1990), Lekkas (1993), Lipovac (1994), Mouzelis (1994), Nitsiakos, (1995), Tsoukalas (1996) and Ventura (1993), are mentioned. On the other hand, anthropologists, social anthropologists and sociologists such as Danforth (1989) and Hirschon-Filippaki (1993) negotiate the formation of ethnic identities with a cultural and social reference point of refugees after the Asia Minor Catastrophe of 1922 and after their relocation to Greece. Also, research is published on the critical treatment of the concepts of culture and cultural identity under the terms of the theory of cultural and social construction, such as those of Papataxiarchis and Paradellis (1993), and Paschalidis (2000). Finally, ethnographic studies with anthropological orientation emerge, the data of which come from field research, which refers to specific ethnic groups, such as, for example, the studies of Gefou-Madianou (1999), Lafazanis (1997) and Tsimpiridou (1994).

From the 1990s onwards, there has been an explosion of interest in identities in Greece, by researchers mainly of ethnographic and anthropological orientation. In their studies, these researchers use dance as an interpretive tool and a means of negotiation, exploring the social process of identity formation with reference to dance. Using analytical tools of dance, including also interpretive tools from the fields of ethnography, social, cultural, political and historical anthropology and folklore, they negotiated the construction of collective identities. More specifically, they approached dance as a point of reference, but, also, as a means of negotiating and managing cultural identity (Koutsouba, 1997; Sarakatsianou, 2011; Tsouraki, 2013), dance identity (Boulamanti, 2014; Panopoulou, 2001; Papakostas, 2007), gender identity (Cowan, 1998; Dimopoulos, 2011, 2017), ethnic identity (Filippidou, 2011, 2019), national identity (Cheilari, 2009; Filippidou, 2019; Kalogeropoulou, 2013; Margaris, 2004;) and identity politics (Fountzoulas, 2016; Manos, 2002; Van Overschelde \& Piatt, 2020).

Therefore, in Greece, from the 90's onwards, culture began to be considered as a dynamic and historical field, which is the subject of negotiation in the formation of collective identities. Dance and rituals begun to be treated as dynamic historically determined processes, which are subject to continuous negotiation. Particularly, the contribution of the ritual to the construction of identity began to be recognized in recent years by sociologists and anthropologists (Bauman, 1992; Connerton, 1989; Geertz, 2003; Turner, 1967, 1969). According to anthropologist Clifford Geertz (2003), rituals embody all those cultural expressions and aspects of a nation or ethnic group, which their members can display and in this way communicate their culture to people who are not part of it, namely to the "others". As follows, ritual practices are those practices through which communities "remember" and enhance their unity, while redefining their relations with their "self" and the "others" both in practical and symbolic terms (Bauman, 1992; Connerton, 1989; Turner, 1967, 1969). 
However, dance usually constitutes an integral part of overall ritual structure, at least in the case of Greek traditional dance (Filippidou, 2019; Fountzoulas, 2016; Kosmatou, 2014; Lantzos, 2003; Niora, 2009; Sarakatsianou, 2011). Nevertheless, dance, as a kind of human behavior, forms an integral part of the overall structure of a cultural communication system (Filippidou, 2019). Hecht et al. (2005) define communication as a way of constructing identity. According to the cybernetic tradition of communication, "when two people communicate [...] they define their relationship by the ways they interact" (Watzlawick, Beavin, \& Jackson, 1967, pp. 120-121). In the cybernetic approach, relationships that are produced in a group, consist of patterns of interaction "in which individuals' words and actions affect the responses of others" (Littlejohn \& Foss, 2012, p. 234). The people that belong to a group, continually adapt their actions to the reactions of "others" based on the feedback they receive from them.

Therefore, through the lens of Cybernetics, communication is perceived as a system of parts, or variables, that influence one another, shape and control the character of the overall system, and, like any other organism, they attain both balance and change. Thus, according to the cybernetic model of communication, "...particular emphasis is placed not on the message per se but on the aims that are pursued with the transmission of it..." (McQuail \& Windahl, 1993), and the relationships that are shaped from the accomplishment of the aims among the communicating groups. Because of that, it can be argued that Cybernetics can be adopted as a starting point for the interpretation of both individual and collective identification. In fact, this is the case in this paper.

However, though Cybernetics as a theoretical model for the communicative construction of the identity has been widely applied, its use in humanities and social sciences under the concept of socio-cybernetics is very recent (Almaguer-Kalixto, Amozurrutia, \& Servós, 2014; Bartscht, 2013; Brigas, 2019; Connell, 2002; Corning, 1996; Dagdilelis, 2018; Degele, 2008; Froese, \& Fernández, 2014; Geyer \& van der Zouwen, 1996; Hay \& Flynn, 2015; Mezza-García, Scott, 2009; Parker, 2019; Stokes, 2006, 2007). Furthermore, although the Greek traditional dance is the subject of multidisciplinary research, and its relationship to identity formation has been approached in various ways, the literature review shows the absence of work focusing on the relationship between identity and dance approach of this under the terms of communication, control and interaction, theories that fall under the governmental theory of communication and this is the research gap that is intended to be completed with this paper.

In particular, the field research of the paper is the dance event of " $\mathrm{K}$ 'na", which is performed within the wider area of Thrace. This dance event constitutes a ritual practice in Greek Thrace during which dance is an integral part. Moreover, the name of dance is also «K'na». The term «K'na» is used by the Thracians both for the event and the dance performed during it. Additionally, it must be mentioned that the dance that accompanies this event, takes many forms in the various areas and ethnic groups of Greek Thrace, while it can be differentiated even among the same ethnic group (Filippidou, 2019; Filippidou, Koutsouba, \& Tyrovola, 2013; Filippidou, Koutsouba, Lalioti, \& Lantzos, 2018, 2019). In this paper, the emphasis is on the Thracian ethnic group of Arvanites of Neo Cheimonio and the way this group performs the dance during event of "K'na" and does not refer to all the ethnic groups living in the area.

The Arvanites of Thrace come from two main immigration waves of Albanian-speaking Orthodox Cristian populations from the region of Bithkoukio (Epirus) to the current Turkish Thrace (Dalatsis, 2012). The emigrations took place in two phases. The first one took place in the mid16th century as a consequence of the participation of Arvanites in the construction of the mosque "Selimie" of Adrianoupoli. As a result, the village of Mandritsa was founded in the actual GreekBulgarian borders, as well as the village of Megalo Zaloufi on the northern part of today's area of Turkish Thrace (Dalatsis, 2012). The descendants of the refugees of the Megalo Zaloufi are the 
inhabitants of Neo Cheimonio, who were forced to emigrate to the west of the river Evros, after the Asia Minor Catastrophe. Therefore, today Neo Cheimonio is a purely Arvanitic-speaking community on the north of Evros prefecture in Greece (Filippidou, 2019).

The dance event of "K'na", as performed in the ethnic group of Arvanites, is studied through the positivist example of cybernetics theory and the hermeneutical model of anthropology. This bifold approach is also based on the fact that dance constitutes both an act and a process (Koutsouba, 1997), both the "final" product and the process. Therefore, the simultaneous and the double dimension of the dance allows a two-way approach regarding the science of dance, both through the positivist model (positive sciences, final "product") and the hermeneutical model (humanities and social sciences, "process"). The basic assumption of this paper is the emphasis given to dance per se, with its own methods and techniques, as well as to the Greek traditional dances and the three-dimensional nature of it, consisting in music, songs and dance (Filippidou, 2011).

The aim of this paper is to investigate whether the different aspects of the three-dimensional nature of dance, as reflected in the "K'na" dance event amongst the Arvanites ethnic group of Neo Cheimonio (Evros), are related with issues of research and shaping of the ethno-cultural identity under the terms of socio-cybernetics.

\section{Methodology}

The methodological process consisted of three steps, namely data collection, analysis and interpretation. Data was gathered through the ethnographic method as this is applied to the study of dance (Buckland, 1999; Giurchescu \& Torp, 1991; Koutsouba, 1999; Sklar, 1991) and based on primary and secondary sources. Primary sources refer to data gathered through fieldwork that was carried out at the region of Thrace, and particularly at the community of Neo Cheimonio from December 2012 up to December 2017. The informants consisted of 53 indigenous inhabitants from the Neo Cheimonio, aged 20-87 years, of different, educational, social and economic level. A sample of expediency was used, where based on the subjective judgment informants were selected who may be reliable, providing safe data. Primary sources refer to the data coming from in-situ research, through interviews (open-type questions for semi-structured interview and unstructured interview), and through participant observation combined with simultaneous audio and video recording of the inhabitants of the community.

Oral history was also used as a method, through which everyday memory is projected as a quest of social history (Thomson, 2002). The overall course of field research was performed by the dual experience of the local culture with reference both to the habitants of this particular community (carriers of the local culture), as well as to the researchers (Erixon, 1967). Secondary sources refer to the review and use of the existing literature based on the principles of archival ethnography (Gefou-Madianou, 1999; Stocking 1992) and historical research in dance (Adshead \& Layson, 1986).

For the collection, presentation and analysis of the data, Geertz's model of "thick description" (2003) was adopted. The recording of the of the different types of "K'na" was based on the notation system of Laban (Hutchinson, 1977; Koutsouba 2005), the analysis of its structure and form was based on structural-morphological and typological model (I.F.M.C. Study group for folk dance terminology, 1974; Martin \& Pessovar, 1961, 1963), as proposed and used in the analysis of Greek traditional dance (Filippidou, 2011, 2019; Koutsouba, 1997, Tyrovola, 2001) and their comparison was based on the comparative method (Holt, \& Turner, 1972; Ogurchov, 1983). The analytical meaning of "myself"/"someone else" and "us"/“others" (Gkefou-Madianou, 1999) that signify the identity as a cultural and social structure were the means of making the voices these 
people heard giving them the opportunity to become informative. Finally, the interpretation of the data was based on the theoretical visuals of the social-cybernetic according to the control model of identity that Burke (1991ab) proposed.

Urged by Cybernetics theory, Burke (1991a) structured a model of identity control (Identity Control Theory - ICT) in which the process of formulation of identity results from the process of control (Burke, 1980, 1991b,1995,1996,1997, Burke \& Cooper 2000, Burke \& Stets 1994; Ellestad \& Stets, 1998; Gekas \& Burke1994; Simmons, Smith, Erez, Burke \& Pozos, 1998; Stets, 1995). More analytically, Burke (1991) considers that identity consists of a set of meanings, which include symbolic and non-symbolic parameters (Burke \& Freese, 1989; McCorkle, 2020; Ritter, 2020). These notions are applied in an individual while being in a social situation, a fact which determines who someone is (Burke \& Tully, 1977). This set of meanings functions as a point of reference, namely an identity standard.

According to the model of Burke, when an identity activates, a circle of feedback is created which consists of four structural elements (Stokes, 2006, 2007) which are: a) the standards of reference or adjustment (an overall of self-meanings) b) the input of information from the environment or a social situation, including reflected appraisals of the perceptions related to self c) the process which compares the input of information to the standards of function of a comparator and finally, d) the output to the environment in which it was compared to which is the source of behavior that aim to bring the introductory exceptional information in connection with identity standards. (Burke, 1991a) (See Figure 1).

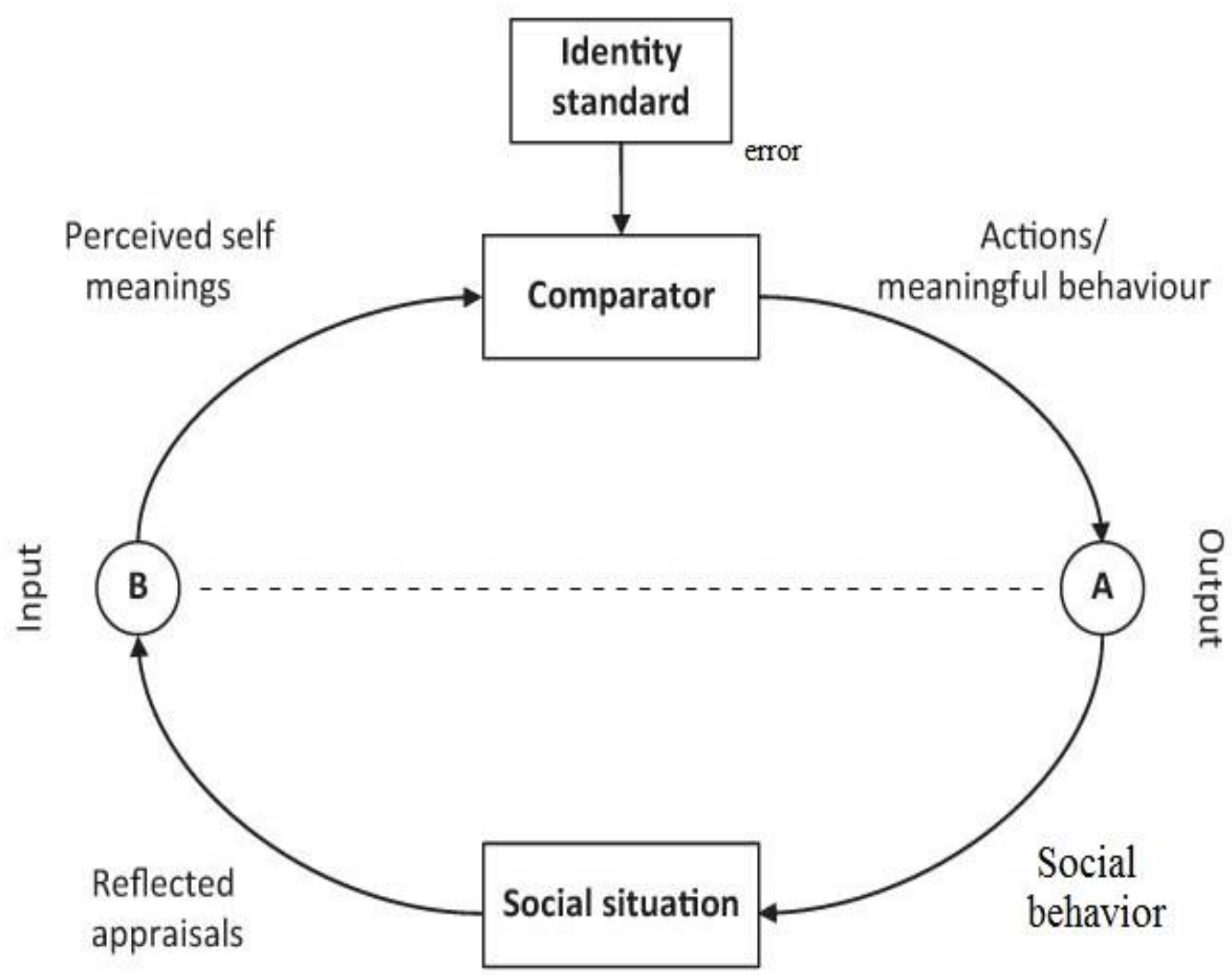

Figure 1. Identity Control Theory-ICT

(Burke, 1991a) 
This model functions by converting the output, meaning the behavior in a social situation, with the aim to change the incoming information (input) that concern reflected appraisals of self. This is done, in order to match internal standards (Burke, 1991a), meaning it tries to self-control the introductory perceptional information it receives.

Based on the above, in this paper, the dance event of "K'na" as performed in the ethnic group of Arvanites, is studied through the positivist example of cybernetics theory and the hermeneutical model of anthropology. This bifold approach is also based on the fact that dance constitutes both an act and a process (Koutsouba, 1997), both the "final" product and the process. Therefore, the simultaneous and the double dimension of the dance allows a two-way approach regarding the science of dance, both through the positivist model (positive sciences, final "product") and the hermeneutical model (humanities and social sciences, "process"). The basic assumption of this paper is the emphasis given to dance per se, with its own methods and techniques, as well as to the Greek traditional dances and the three-dimensional nature of it, consisting in music, songs and dance (Filippidou, 2011). In this way it is a combined study that is absent from the study of dance.

\section{The ethnographic context: The Arvanites (the refugees) and the "others" (the locals)}

The area of Greek Thrace, from 1910 to 1930, was a space of resettlement of populations from Ionia, Pontos, Cappadocia, but also from the Bulgarian and Turkish Thrace, with the majority of them settling in the area of Evros (Filippidou, 2011, 2019). As it happened in the entire continental Greece, likewise in Thrace, refugees were treated in a hostile way by the local people upon their arrival. Besides, the Greek society had already shaped their own images about their compatriots who lived in the Turkish territory, which were negative even since the era of 1916. During that period, on one hand, the Athens Labor Center was pursuing the banning of recruitment of refugee workers, and, on the other hand, the groups of "Epistratoi" (the "Reservists", royalist paramilitary organization in Greece during World War I,) led by Dimitrios Gounaris and Ioannis Metaxas were organising a "pogrom" against refugees, accusing them of being political supporters of Venizelos (Agtzidis, 2010).

In the area of Evros, refugees were treated dismissively, and they were called names such as "Turks" or "Turkseeds", insults that, according to Livieratos (1985, pp. 27) "along with related swearwords, such as skatoougloudes, paliaoutides, etc. were used on an everyday basis by superior and inferior administrative officials". This attitude was mostly due to the competition regarding the land appropriation, the exchangeable land parcels, since local people thought that the refugees were going after their properties; therefore, the cohabitation of local people with the refugees turned out to be quite difficult (Gurer, 2019). This treatment had also to do with the place of origin of the refugees, since the resettlement area was the borderland with Turkey, the "national enemy" according to the perception of the local people. Due to the above elements, the two sides presented elements of intense introversion, rallying, and severe rivalry. As a direct result, the term "refugee" included a pejorative significance on the minds of the inhabitants of Evros, which led them to exclude that group from their social integration or an upward social mobility (Filippidou, 2019).

The above led to a lack of smooth communication amongst the inhabitants of the area. However, communication is a basic component of a harmonic cohabitation, as it gives people the perception that they belong to a socio-cultural unit, in other words, to a group (Vrizas, 2005). However, the groups are part of bigger groups that interact with each other. The community of Neo Cheimonio belongs to the group of refugees, as does the group of Evrites that has a Greek conscience, but also a special ethno-local identity (Filippidou, 2019). 
For instance, the inhabitants of Neo Cheimonio present various social identities, as they define themselves as Cheimoniotes (originary from Cheimonio), Arvanites, Thracian refugees from Turkish Thrace, but also Greeks. These identities interact with one another, in other words, they are in direct interdependence, as each identity is always limited, because of its dependence on other identities. This interdependence leads to the establishment of an identity standard for the group of Arvanites in Neo Cheimonio.

However, this identity standard defining the Arvanites group was in contrast with the surrounding social space, since local people of the region pushed them to the social margin, considering them to be non-Thracians, non-Evrites (originary from the area of Evros) and in many cases, what is more, as non-Greeks, as the case of Turkish-speaking Gagauzes of Oinoi village and Arvanites of Neo Cheimonio. Accordingly, the local people of the area, in their attempt to expel refugees of the area in order to take advantage of the exchangeable land, which they considered to be theirs, gave them an inferior identity. Due to that, the term "refugee" acquired a connotation of inferiority, and, also, a meaning of national dissimilarity (Filippidou, 2011, 2019).

The attitude of the local people created inferiority feelings amongst the refugees, which, nevertheless, were not congruent with the identity standard they had developed until then and the previous self-perception of them. According to Burke (1991), when there is incongruence between the environmental input and the identity standard, a new parameter emerges, the one of distress (sadness) which drives individuals into action. Likewise, in the case of refugees in the area of Evros, the fact that local people attributed a stigmatized and inferior identity to them directly led to the modification of their behavior, in order to restore their identity.

\section{Some remarks on the "K'na" dance event}

The "K'na" is a wedding dance event that enjoys great popularity in Africa and Asia. In Greece, this dance event can also be found in the population groups that emigrated from Turkey (Filippidou, 2019; Filippidou, Koutsouba, Lalioti, \& Lantzos, 2018, 2019). That dance event seems to enjoy an overall acceptance and popularity in the wider area of Thrace, as it is performed by most of the ethnic groups of the area, and, in fact, is still alive up to today in several cases.

As regards the name of the "K'na" dance event, there is no clear information. Most of the informants, when asked" why this custom is called "K'na", reply that "this is how our ancestors called it, so did we". However, most of them denoted the importance of the henna that is used during the performance of the event, without knowing the reason why they did it. The dance event is performed on the eve of the wedding, mainly at the bride's house (Filippidou, 2010, 2019; Filippidou, et al., 2018, 2019) and the "basic ritual acts of the custom present differences in the individual ritual roles amongst the villages of Evros..." (Spanos, 2016, p. 59). In other words, the "K'na" dance event is generally the same amongst all the groups of the area that perform it, whereas slight variations are observed locally, due to issues related to the shaping of the local cultural identities (Filippidou, Koutsouba, \& Tyrovola, 2013).

In more detail, on that same night, the night before the wedding ceremony, a farewell party is held at the house of the bride as well as at the house of the groom. At the groom's house his family celebrates the last day of the soon to be groom but now unmarried lad. At the bride's house her family is more sentimentally intense due to it being the last night of the bride celebrating with her friends and family before moving to her husband's home. When all the guests arrive and the party begins the mother in law of the bride along with her relatives bring her "the Baxisia", in other words, her presents. Among those is a small plate with some henna. After they dance "the Baxisia" and then give them to the bride, they take "the Baxisia" from the relatives of the bride to give them 
to the groom by taking them to him and continuing the party there (Filippidou, 2019; Filippidou, et al., 2018, 2019).

Later on, just before the end of the party, three newlywed girls whether by whole or halfblood start preparing the "K'na" meaning the henna in a brass or earthenware plate, by using their right arms. They add water, flour and wine to this and place three lit candles in it. Next, they tie a red thread around the candles while during this preparation of the henna the relatives sing three songs suitable for this special occasion. The songs played are about emigration due to the fact that the bride is soon to leave her family and home and live with her husband and his family (Filippidou, 2019; Filippidou, et al., 2018, 2019).

After this slack preparation of the bride's ring finger and smallest one is painted by a female member of her family. They are painted up to the second phalanx and then tied with two white handkerchiefs or cloths. When this ritual is completed dancing begins with the first one in the line holding in his right hand the holy object of the ceremony which is the three lit candles (Filippidou, 2010, 2019; Filippidou, et al., 2018, 2019).

One of the numerous ethnic groups of the area that perform the dance event of " $\mathrm{K}$ 'na" is the one of Arvanites of Neo Cheimonio.

\section{The dance of "K'na" as an identity-shaping factor in the Arvanites of Neo Cheimonio}

One of the means used by Arvanites in order to change the way people felt towards them was the dance of "K'na", since dance as a special kind of cultural knowledge, can externalize a particular content and abstract meanings (Koutsouba, 1999, 2002). According to Manos (2004), dance is a strategy used by individuals within the process of identity shaping. As a result, dance does not only reflect, but is also capable of shaping an identity (Koutsouba, 2002; Filippidou, 2011, 2019).

As refugee groups from the area of Evros received negative input from the social environment, they adapted their own choreographic compositions of the dance of " $\mathrm{K}$ 'na" to the ones of their fellow townsmen. In this way, they created new dance formations, which were similar to the dances of local people, for the sake of convergence of the two groups and the mitigation of their differences, which would then make the "others" change their perception of them. For instance, the inhabitants of Nea Vyssa village, Greek-speaking refugees from Turkish Thrace, added a second dancing phrase to the "K'na" dance, which led to the creation of a new choreographic composition. This new choreographic composition maintained, on one hand, the previous form of "K'na", which was danced in the same way as when they were in the region of Turkish Thrace, but they added to it a dance phrase which is also found in the dance repertoire of the local people of the area (Filippidou, 2019; Filippidou, Koutsouba, Lalioti, \& Lantzos, 2018, 2019).

However, the only ethno-cultural group that did not modify its kinetic component in the "K'na" dance after arriving to Greece was the one of Arvanites. The paradox regarding that group, as it was shown through research in the community of Neo Cheimonio, was that they were different from the other groups of the area, as they accompanied the wedding dance event of K'na with dance phrases of the Syrtos dance pattern (see Figure 2) (Filippidou, 2019). The latter element was not found within the other groups of the area whose dances follow the pattern of "sta tria" and "sta tria type" (Filippidou, 2019; Filippidou, et al., 2018, 2019). 


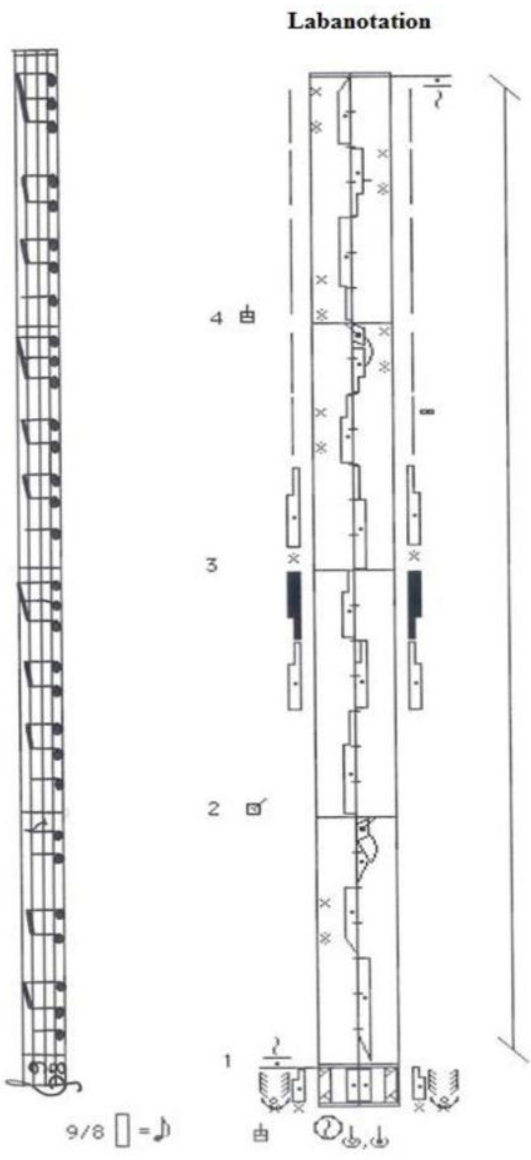

Effort

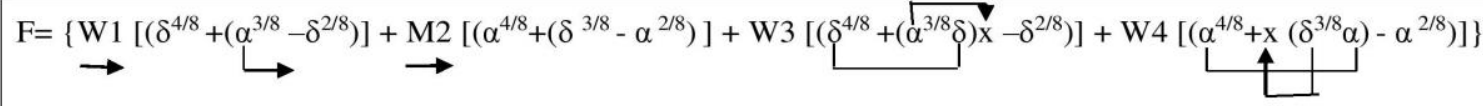

Figure 2. "K'na" dance of the Arvanites of the Neo Cheimonio

This fact in itself testifies a different approach of this group, which after its resettlement in the area of Thrace and in order to get integrated in its new homeland, adopted various elements of the dance tradition of the Thracians, to the extent that its dance repertoire was similar to the one of Thrace. However, as regards the dance that accompanied the custom of K'na, which, as abovementioned, was of predominant importance for the inhabitants of the whole region, the group under study did not opt to integrate and assimilate by adopting the dance phrase "sta tria" which accompanied the dance event of all the ethno-cultural groups of the area, but it kept is dance phrase of Syrtos, which is the most basic dance of Arvanites in the entire Greece (Filippidou, 2019).

Therefore, although Arvanites of Neo Cheimonio did adopt events, customs and dances of Thracians, in order to smoothly integrate into the society of their resettlement land when they arrived from the area of Northern Epirus, however, in the case of such an important event for the region, they maintained the most basic dance of the Arvanites repertoire, the Syrtos. However, they accompanied it with $9 / 8$ and not $7 / 8$ rhythms, as they used to do in Epirus, and choosing this 
differentiation, in order to show their Epirus identity, but also matching this differentiation with the integration, in order to (self-)define themselves as Thracian Arvanites.

As they came from Greek Thrace, the dominance of the inhabitants of the area, mostly because of their Greek-speaking element, burden the refugees with feelings of guilt and drove them to the least possible manifestations of their identity. Their different language was the most significant factor of that inferior identity that was attributed to them. However, this attitude shown not only by the locals, but in general by the Greek-speaking population of the region, affected the perceptions on themselves but also the attitude of Arvanites towards them. Accordingly, they tried to adapt their acts to the reactions of the others on the basis of feedback that they received from them, for the sake of the stability and good functioning of the group, but also in order to achieve their goal, which was no other that their acceptance, their social integration and so on (Filippidou, 2019).

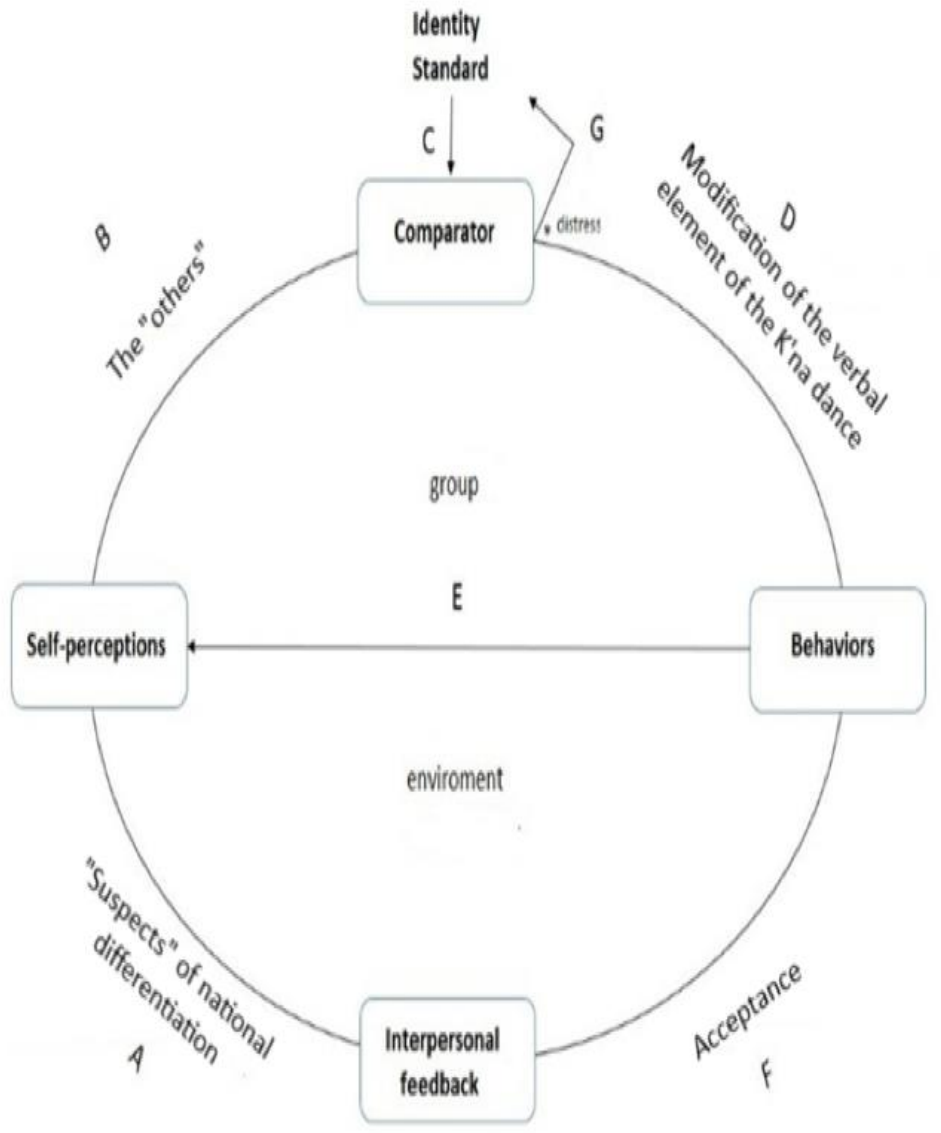

Figure 3. Cybernetic control model regarding the identity of Arvanites of Neo Cheimonio in the period 1924-1970

As they realised that the main reason of their confrontation with the locals was the different language they spoke, they limited its use only at home and for the purposes of their intercommunication, while the Arvanitic-language songs that accompanied the dances were replaced by Greek ones of neighbouring areas, since there was no intention of translating the Arvanitic-language songs. The same occurred with the dance of K'na which was modified as regards its verbal aspect, in order to bring about changes to the behavior of "the other" towards 
Arvanites, so that they could be considered "similar" by the locals, a fact that presented no congruence with the internal standards of Arvanites (Filippidou, 2019) (see Figure 3). However, and in that case, through the dance of K'na, Arvanites of Neo Cheimonio did not only change the verbal and kinetic element, in order to assimilate with the Greek-speaking populations of the area, but also tried to maintain the Arvanitic identity.

Already since the Antiquity, the nations-states were based on two powerful poles, which were no other than the common religion and the common language, which indeed was defined by Anderson (1991) as a "sacred language". Later on, the Neohellenic Enlightenment settled the basis for the perception that " $\ldots$ the imaginary standard of common language, religion and origin $[\ldots]$ was the one and predominant feature of the neohellenic state [...]" (Tsitselikis, 1999, p. 759).

Accordingly, the newly established Greek state was driven to the "construction" of a national identity, through " ...the delimitation and the standardization of a special national tradition, which could be used as an exclusive and crystallized ideology..." (Mastoraki, 2003-2004). Therefore, the figure "of the same blood-of the same religion-of the same language" was adopted, which in turn incarnated the desire for the homogenized national identity and found its foundation in the Antiquity. Any divergence from the elements of this figure, by the elements of the Greekness, was considered as an element of national differentiation, and was judged as a "suspect enemy" of national cohesion (Filippidou, 2011).

During the period of the imposition of the Colonels' dictatorship (commonly known as Junta), the Greek ruling class of that period, based on the "Greek Orthodox tradition" tried to shape a unitary national Greek identity, through the "doctrine of the national unity" (Karageorgou, 2001, pp. 13). That common "Greek conscience", as it was self-defined, had its basis on the public obligatory education, which was directed by the dictatorship regime. The education was used as the basis to pursue the creation of a "given" tradition that would be transmitted to anyone who would receive said education. Dance was one of the cultural elements that were chosen for the mitigation of the differences within the country, by means of which national homogeneity would be also projected towards the foreign countries.

Accordingly, "Panhellenic" dances during the time of the so-called Junta flourished and came to the forefront once again (Loutzaki, 1994), with Tsamikos and Kalamatianos being converted into national symbols (Koutsouba, 1995, 2014). Therefore, by teaching the "panhellenic" dances to the school students, a common national cultural identity was adopted (Fountzoulas, 2016; Fountzoulas, Koutsouba, Hapsoulas \& Lantzos, 2016). In the multicultural area of Evros, due to the numerous ethnic groups that lived there, the oligarchic regime of the Junta introduced local dances of Thrace into the school programme of taught dances (Filippidou, 2019). However, the local particularities of each ethnic group and each community were ignored and homogenised on the basis of the idea of a unitary national conscience. Therefore, instead of them, a "panthracian" dance repertoire was created (Filippidou, 2011) which was imposed over anyone that presented different characteristics.

The dance of "K'na", despite the changes it suffered in order to adapt to the opinions of the "others" still had elements that designated their special ethno-local identity of the communities under study. Those elements, on one hand, would be considered as "suspect" of differentiation, and, on the other hand, would diversify the inhabitants of the region, as opposed to the target of the Junta, which was the "national cohesion". Therefore, in order for the refugee groups of the area of Evros to maintain their harmony, as the latter does not come automatically after assuming any action, they tried to self-regulate the preceptory input that they received on behalf of the "others". Therefore, they followed the identity standard that was imposed by the dictatorship of the Coronels 
and adopted the dance form of the "Panthracian" repertoire, which was established in order to enhance the image of the Greek Christian culture (Filippidou, 2019).

However, in the case of the Arvanites ethnic group of Neo Cheimonio a completely different situation was being shaped. The Arvanites of the community during the last time period changed the verbal element of their K'na dance and ignored their language, in order to be recognized as Thracians by the local people of the region. In this way, they approached the figure "of the same language-of the same religion" which was promoted, both regarding the ruling class of the newly established state and the oligarchy regime of the specific period, which applied it with even more ardor. However, the element "of the same kind" and "of the same blood" would not fit in all the elements of their identity, as, through the study of the dance " $\mathrm{K}$ ' na", it is concluded that the latter diverges from the dance pattern which was promoted in the area (Filippidou, 2019).

Despite the above, the dance of "K'na" in Neo Cheimonio during that period of time remained the same. By changing its verbal element and maintaining it as such in this new situation, the Arvanites modified the incoming information they received from their social environment, which was now positive towards them (Filippidou, 2019). During the dictatorship of the Junta, the input received from the social interaction with the "others" was not differentiated. That occurred since the Syrtos dance pattern, or in other words, Kalamatianos, had been converted into a national symbol (Foutzoulas, 2016) already since the establishment of the Greek state. As a national symbol, the choreographic composition of "K'na" was maintained, since their behavior would not affect the interpersonal relations with their social background. Therefore, the Arvanites' identity during that period did not undergo any differentiation, since the meanings that they received from their environment were overwhelmingly positive insofar as their identity was in compliance with the figure "of the same language-of the same religion-of the same blood". The above led to the maintenance of their positive self-perception, which was still congruent with their identity standards (Filippidou, 2019) (see Figure 4).

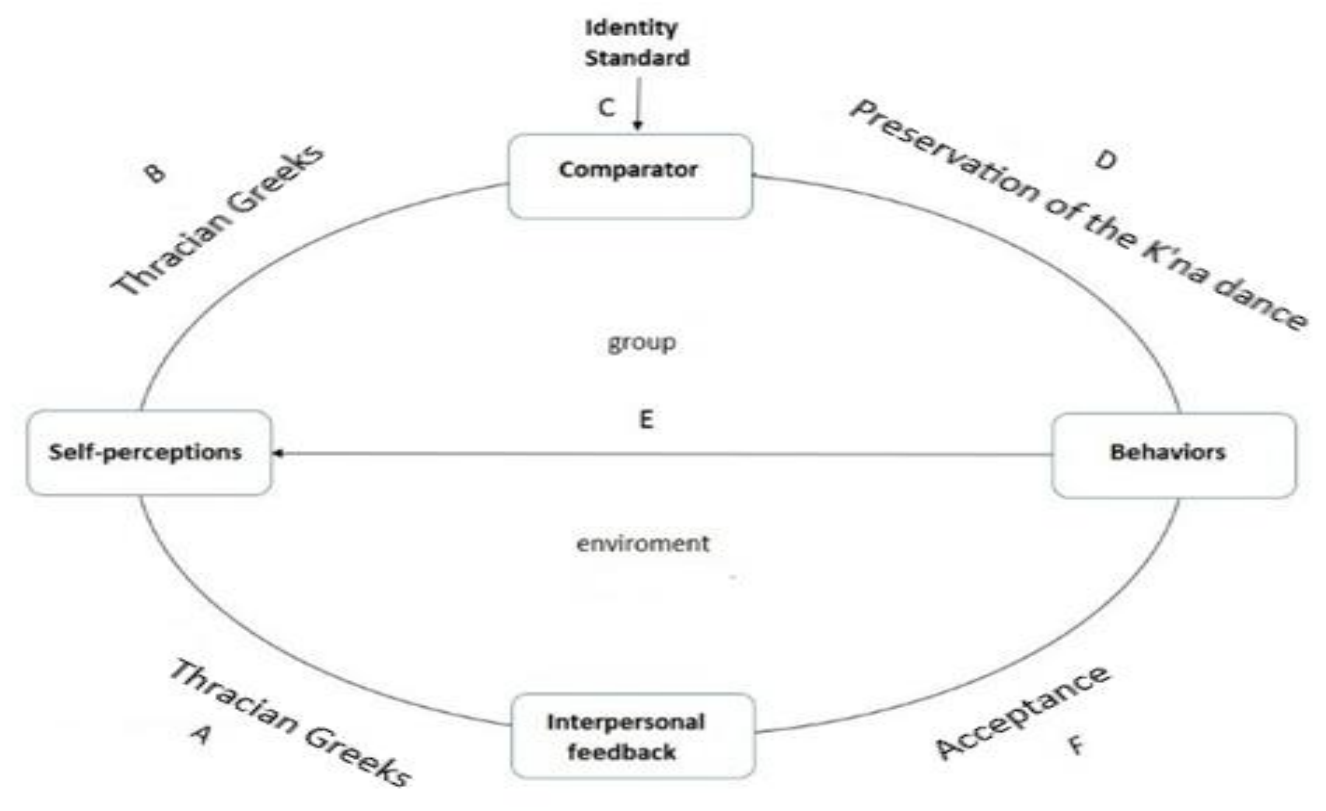

Figure 4. Cybernetic control model regarding the identity of Arvanites of Neo Cheimonio in the period 1970-2017 
Finally, studying the identity of the Arvanites of the Neo Cheimonio, it is found that it did not remain stable. The stigmatized and inferior identity given to them by the locals, forced the Arvanites to take action by differentiating aspects of their identity. In order to justify the existence within all local communities in the area and to eliminate the derogatory title "refugee" for which they were accused, they adopted from the three-fold dimension of dance (music, dance and speech) the component of speech in the way used by the local people. Later, with the predominance of the junta, while all the ethnic groups in the area changed the choreographic composition of the dance to match the one proposed by the political authorities of the time, the Arvanites retained it. This happened, as the "K'na" dance of the Arvanites was similar to the "Kalamatianos" dance, one of the national cultural symbols of the Greek state. As a result, the choreographic composition of Syrtos was maintained in the event of K'na, which was also accompanied by $9 / 8$ rhythms. Thus, the Arvanites of Neo Cheimonio preserved the Arvanitan identity, which resembles their origin and their connections with Epirus. However, the act of bartering away their language and adopting a 9/8 rhythm, which is widely used in the area of Thrace, united and equated them with the local people. Additionally, the preservation of the Syrtos pattern, one of the national dance symbols of Greece, gave them the Greek identity. Therefore, even today the people of Neo Cheimonio boast of being Greek, Thracian and Arvanites, referring to all the identities that they shaped during their long journey. Consequently, the Arvanites, by readjusting the dance of "K'na", always in conjunction with the reaction of the "others", self-regulate their incoming preceptory input they receive, in order to balance their internal standards with the perception of them as expressed by the "others".

\section{Conclusions}

This paper examined the cybernetic construction of the ethno-cultural identity within the context of the wedding dance event of "K'na", as it is performed in the community of Neo Cheimonio (Greek Thrace), the homeland of many Arvanites refugees. The cybernetics approach was used as a theoretical background, as it is determined by Burke's (1991) theoretical model, but also the analysis of the "K'na" dance per se. The combination of these two parameters, both the recording and analysis of the dance per se and the analysis and interpretation based on Burke's (1991) theoretical model, constituted the structure on which this study was based, providing a holistic approach to dance research.

From the analysis and comparison of the data, it was found that the "Kna" dance did not remain the same over the years, but it went through changes, depending on the circumstances and in relation to the reactions of the "others". On the bases of these results, theoretical issues were further examines. The results of the analysis were interpreted through the lens of the theoretical concept of Cybernetics. Based on this concept, the "K'na" dance in this study is perceived as a symbol and as a "container" of meaning.in these sense, it can be used, among other things, as a means of acting and counteracting towards the feedback received from "others". Therefore, dance is viewed as an indicator of the "construction" of identity.

More specifically, the "Kna" dance of the Arvanites of the Neo Cheimonio shapes and reshapes their collective identity, as the Arvanites use it to react to the messages they receive from their communication with the "important others". By adapting the dance of "Kna" in accordance to the reactions of "important others", the Arvanites self-regulate the incoming information. Thus, they balance their internal standards, with the evaluations of the "others" towards "them". Therefore, through the example of the "K'na" dance, it was found that the "construction" of an 
identity arises as a constant process of self-regulation and internal control, proving that the shaping of the identity is a cybernetic process (Filippidou, 2019).

In conclusion, though Burke's model has not yet been used in the study of dance, the example of the "K'na" dance event, as this is performed by the Arvanites of the Neo Cheimonio, proves to be applicable in this case. As a result, the model seems to apply not only to individuals, but also to groups. By combining the analytical tools of dance with the model of identity control, an opportunity to explore issues related to the formation and reformation of a group's collective identity is revealed, proving that identity is a "construction" that results from communication and interaction with "other" groups.

\section{References}

Adshead, J., \& Layson, J. (eds.). (1986). Dance history: A methodology for study. London: Dance Books.

Almaguer-Kalixto, P., Amozurrutia, J., \& Servós, C. M. (2014). Policy processes as complex systems: The case of Mesoamerican sustainable development initiative. Journal of Sociocybernetics, 12, 31-52.

Anderson, B. (1991). Imagined communities: Reflections on the origin and spread of nationalism. London: Verso.

Avdela, E. (1995). The socialism of "others": Class struggles, ethnic conflicts and gender identities in post-Ottoman Thessaloniki. Istorika, 18-19, 171-204.

Barth, F. (1969). Introduction. In Frederick Barth (eds.), Ethnic groups and boundaries: The social organization of culture difference (pp. 9-37). Boston: Little Brown and Co.

Bartscht, J. (2013). The cybernetics of authenticity. Kybernetes, 42(4), 528-543.

Beckett, G. H., \& Kobayashi, M. (2020). A Meta-study of an Ethnographic Research in a Multicultural and Multilingual Community: Negotiations, Resources, and Dilemmas. American Journal of Qualitative Research, 4(1), 85106. https://doi.org/10.29333/ajqr/8267

Boulamanti, S. (2014). Greek traditional dance and gender complementarity: Cultural habits and hierarchy in the castle of the country of Chios. Unpublished Master's thesis. Athens: Department of Physical Education and Sport Science, National and Kapodistrian University of Athens.

Brigas, C. (2019). Modeling and Simulation in an Educational Context: Teaching and Learning Sciences. Research in Social Sciences and Technology, 4(2), 1-12. https://doi.org/10.46303/ressat.04.02.1

Buckland, J. Th. (1999). Introduction: Reflecting on dance ethnography. In T. Buckland (Eds.), Dance in the field: Theory methods and issues in dance ethnography (pp. 1-10). Great Britain: Macmillan Press.

Burke, P. J. (1991a). Identity processes and social stress. American Sociological Review, 56, 836849.

Burke, P. J. (1991b). An identity theory approach to commitment. Social Psychology Quarterly, $54,239-251$.

Burke, P. J. (1995). Identities and self-verification in the small group. Social Psychology Quarterly, $58,61-73$.

Burke, P. J. (1996). Social identities and psychosocial stress. In H. Kaplan (eds.), Psychosocial stress: Perspectives on structure, theory, life course, and methods (pp. 141-174). Orlando, FL: Academic Press. 
Burke, P. J. (1997). An identity model for network exchange. American Sociological Review, 62, 134-150.

Burke, P. J., \& Cooper, C. L. (2000). The organization in crisis: Downsizing, restructuring, and privatization. Oxford: Blackwell Publishers.

Burke, P. J., \& Freese, L. (1989). Identity and social structure: Annual meeting of the American Sociological Association. San Francisco, CA.

Burke, P. J., \& Reitzes, D. C. (1981). The link between identity and role performance. Social Psychology Quarterly, 44, 83-92.

Burke, P. J., \& Stets, J. (1994). Inconsistent self-views in the control identity model. Social Science Research, 23, 236-262.

Burke, P. J., \& Tully, J. (1977). The measurement of role/identity. Social Forces, 55, 881-897.

Burke, W. W. (1980). Systems theory, gestalt therapy, and organization development. In T.G. Cummings (eds.), Systems theory for organizational development (pp. 20-22). New York: Wiley-Interscience.

Cheilari, A. (2009). Local and national identity in motion: The example of Tsakonian dance in Leonidio, Arcadia. Unpublished Master's thesis. Athens: Department of Physical Education and Sport Science, National and Kapodistrian University of Athens.

Cohen, A.P. (1994). Boundaries of consciousness, consciousness of boundaries: Critical questions for anthropology. In H. Vermeulen, \& C. Govers (eds.), The Anthropology of Ethnicity: Beyond "Ethnic Groups and Boundaries" (pp. 59-82). Amsterdam: Het Spinhuis.

Connell, J. D. (2002). Multiple constructions of the environmental crisis: A sociocybernetic view. Journal of Sociocybernetics, 3(2), 1-12.

Connerton, P. (1989). How societies remember. Cambridge: Cambridge University Press.

Corning, P. A. (1996). Synergy, cybernetics and the evolution of politics. International Political Science Review, 17, 91-119.

Cowan, J. (1998). Body policy: Dance and sociability in northern Greece (E. Papagaroufali, eds. \& K. Kouremenos, translation). Athens: Alexandria.

Dagdilelis, V. (2018). Preparing teachers for the use of digital technologies in their teaching practice. Research in Social Sciences and Technology, 3(1), 109-121. https://doi.org/10.46303/ressat.03.01.7

Dalatsis, D.Ch. (2012). The Arvanites of eastern Thrace. Athens: Noon publication.

Danforth, L. (1989). Firewalking and religious healing: The anastenaria of Greece and the American firewalking movement. Princeton: Princeton University Press.

Demertzis, N. (1996). The reason of nationalism: An ambiguous semantic field and modern trends. Athens: Papazisis.

Dimopoulos, K. (2011). Area components and gender dance practices: The lowland and mountainous communities of Karditsa, Thessaly and the period 1920-1980. Unpublished Master's Thesis. Athens: Department of Physical Education and Sport Science, National and Kapodistrian University of Athens.

Dimopoulos, K. (2017). Timeless and contemporary processes in the "game" of constructing gender identity: Dance and gender transformation in the community of Megalon Kalivia Trikala Thessaly. Unpublished Ph.D. Thesis. Athens: Department of Physical Education and Sport Science, National and Kapodistrian University of Athens.

Ellestad, J., \& Stets, J. E. (1998). Jealousy and parenting: Predicting emotions from identity theory. Sociological Perspectives, 41, 639-668.

Erixon, S. (1967). Urgent-ethnological tasks. Ethnologia Europaea, 1, 163-169. 
Filippidou, E. (2010). Recycling the tradition: The dance in Nea Vyssa, northern Evros. Alexandroupolis: Municipality of Vyssa.

Filippidou, E. (2011). Dance and identity search: Acculturation and retribalization strategies of Inoi Gkagkavouz in Evros. Unpublished Master's thesis. Athens: Department of Physical Education and Sport Science, National and Kapodistrian University of Athens.

Filippidou, E. (2019). Crossing the borders, uniting the people: Cybernetic dance approach at the Thracian wedding event of "K'na" in Greece and Turkey. Ph.D. thesis. Athens: Department of Physical Education and Sport Science, National and Kapodistrian University of Athens.

Filippidou, E., Koutsouba, M. \& Tyrovola, V. (2013). Interweaving dance, ritual and identity: The dance at the "K'na" ritual as a reference point for the formation of the local cultural identity at the Greek region of Evros. Science of Dance, 6, 19-40. Available at: http://www.elepex.gr/images/stories/ektostomos/filippidou-kna-full-text-gr.pdf.

Filippidou, E., Koutsouba, M., Lalioti, B., \& Lantzos, V. (2018). Cybernetic approach of the "K'na" dance: The construction of ethnic and national identity in Nea Vyssa, Thrace, Greece. Mediterranean Journal of Social Sciences, 9(2), 17-29. Available at: https://content.sciendo.com/view/journals/mjss/9/2/article-p17.xml

Filippidou, E., Koutsouba, M., Lalioti, B., \& Lantzos, V. (2019). The construction of national identity through cybernetic process: The example of "K'na" dance event in Greek and Turkish Thrace. European Review of Applied Sociology, 12(18), 13-31. Available at: https://content.sciendo.com/view/journals/eras/12/18/article-p13.xml.

Fischer, M. (1986). Ethnicity and the post-modern arts of memory. In J. Clifford, \& G. Marcus (eds.), Writing culture: The poetics and politics of ethnography (pp. 194-233). Berckley, Los Angeles \&London: University of California Press.

Fountzoulas, G. (2016). Dance and politics: Positions and contrasts in the dance event "Gaitanaki" in Skala and in Dafni, Nafpaktia Greece. Unpublished Master's thesis. Athens: Department of Physical Education and Sport Science, National and Kapodistrian University of Athens.

Fountzoulas, G., Koutsouba, M., Hapsoulas, A. \& Lantzos, V. (2017). The transformation of the intangible cultural heritage of dance through state education and politics in the ritual of a rural Greek community. Mediterranean Journal of Social Sciences, 8(1), 243-251.

Gecas, V., \& Burke, P. J. (1994). Self and identity. In K. S. Cook, G. A. Fine, \& J. S. House (eds.), Sociological perspectives on social psychology (pp. 41-67). Boston MA: Allyn and Bacon.

Geertz, C. (2003). Thick description: Toward an interpretive theory of culture. In C. Geertz (eds.), The interpretation of cultures: Selected essays (pp. 1-30). New York: Basic Books.

Gefou-Madianou, D. (1999). Culture and ethnography. From Ethnographic realism to political criticism. Athens: Ellinika Grammata.

Gellner, E. (1983). Nations and nationalism. Oxford: Basil Blackwell.

Geyer, F., \& van der Zouwen, J. (1996) Cybernetics and social science: Theories and research in sociocybernetics. Kybernetes, 25, 59-59.

Giurchescu, A., \& Torp, L. (1991). Theory and methods in dance research: A European approach to the holistic study of dance. Yearbook for Traditional Music, 23, 1-10.

Gurer, C. (2019). Refugee Perspectives on Integration in Germany. American Journal of Qualitative Research, 3(2), 52-70. https://doi.org/10.29333/ajqr/6433

Handler, R., \& Linnekin, J. (1984). Tradition: Genuine or spurious. Journal of American Folklore, 97, 273-290.

Hanson, A. (1989). The making of the Maori: Culture invention and its logic. American Anthropologist, 91(4), 890-902.

Hay, J., \& Flynn, D. (2015). Changing social focusing in the development of jazz music. Journal of Sociocybernetics, 13(1), 31-48. 
Hecht, M.L., Warren, J.R., Jung, E., \& Krieger, J.L. (2005). A communication theory of identity: Development, theoretical perspective, and future directions. In W. B. Gudykunst (eds.), Theorizing about intercultural communication (pp. 257-278). Thousand Oaks, CA: Sage.

Hirschon-Filippaki, R. (1993). Memory and identity: The Kokkinia refugees from Asia minor. In E. Papataxiarchis, \& Th. Paradellis (eds.), Anthropology and the past: Contributions to the social history of modern Greece (pp. 327-356). Athens: Alexandria.

Hobsbawm, E. (1994). Nations and nationalism since 1780. Cambridge: University Press.

Holt T.R., \& Turner, E.J. (eds.). (1972). The methodology of comparative research. New York: The Free Press.

Hutchinson, A. (1977). Labanotation: The system of analyzing and recording movement. London: Dance Books.

I.F.M.C. Study Group for Folk Dance Terminology. (1974). Foundation for the analysis of the structure and form of folk dance: A syllabus. Yearbook for Folk Music, 6, 115-135.

Kalogeropoulou, S. (2013). Greek dance and everyday nationalism in contemporary Greece. Unpublished Master's thesis. New Zealand: School of Physical Education, Sport and Excersice Sciences. University of Otago.

Karageorgou, M. K (2001). Greek national identity and nationalism: The historical composition of the modern Greek national identity and the role of Europe. Paper presented at the International Conference on European Identity and Nationalism. Rutgers State, University of New Jersey, Center for Russian and Eastern European Studies. Retrieved from www.greekhelsinki.gr/bhr/greek/articles/pr_01_05_01.rtf.

Kitromilides, M.P. (1990). 'Imagined communities' and the origins of the national question in the Balkans. In M. Blinkhorn and T. Veremis (eds.), Modern Greece: Nationalism and nationality (pp. 23-66). Athens, Greece.

Kosmatou, V. (2014). Dance and community relations in Faraklata, Kefalonia, 1950-1960. Ph.D. thesis. Athens: Department of Physical Education and Sport Science, National and Kapodistrian University of Athens.

Koutsouba, I.M. (2002). Cultural identity and dance: A first approach. In The art of dance today: Education, production, performance, proceedings of the art dance conference (pp. 17-24). Athens: Association of Alexander S. Onassis Public Benefit Foundation.

Koutsouba, I.M. (2005). Notation of dance movement: The passage from prehistory to the history of dance. Athens: Propobos.

Koutsouba, M. (1997). Plurality in motion: Dance and cultural identity on the Greek Ionian Island of Lefkada. Ph.D. thesis. London: University of London.

Koutsouba, M. (1999). "Outsider" in an "inside" world, or dance ethnography at home. In T. Buckland (eds.), Dance in the Field: Theory, methods and issues in dance ethnography (pp. 186-195). London: Macmillan Press.

Lafazanis, D. (1997). Mixed villages of Kato Strymon: Ethnicity, community and locality. Synchrona themata, 63, 96-107.

Lantzos, V. (2003). The functionality of dance in the cycle of anasthenism in Kosti of Sozoagatoupolis province. Ph.D. thesis. TEFAA, National and Kapodistrian University of Athens.

Lekkas, P.E. (1993). Nationalist ideology and tradition. Diavazo, 332, 46-50.

Lipovac, Th. (1994). The divided Greek identity and the problem of nationalism. In N. Demertzis (eds.), Greek political culture today (pp. 115-132). Athens: Odysseus.

Littlejohn, S.W., \& Foss, K.A. (2012). Human communication theories. Athens: Pedio. 
Loutzaki, I. (1994). Dance in 'political' rhythms. In I. Loutzaki (eds.), Dance and its socio-political aspects: Dance and costume, proceedings from the 17th symposium of the study group on ethnochoreology (pp. 65-72). Nafplion: Peloponnesian Folklore Foundation \& International Council for Traditional Music.

Manos, I. (2002). Visualizing culture - demonstrating identity: Dance performance and identity politics in a border region in northern Greece. $\mathrm{PhD}$ Thesis. Germany: Universität Hamburg.

Manos, I. (2004). The space as a means of constituting and negotiating identity in the Florina area. In E. Avdikos, R. Loutzaki \& Chr. Papakostas (eds.), Dancing Motley (pp. 51-71). Athens: Greek Letters.

Margaris, Z. (2004). L' Immigration Albanaise en Grece. Danse et indentification. PhD Thesis. Paris: Université Paris 8.

Martin, G., \& Pessovar, E. (1961). A structural analysis of the Hungarian folk dance. Acta Ethnographica, 10, 1-40.

Martin, G., \& Pessovar, E. (1963). Determination of motive types in dance folklore. Acta Ethnographica, 12(3-4), 295-331.

Mastoraki, A. (2003-2004). Triple ritual event and contemporary Greek cultural identity. Retrieved from http: /www.pnevma.gr on 11/11/2010.

McCorkle, W.D. (2020). The Relationship Between Teachers' Grade Level and Views on Immigration and Immigrant Students. Journal of Social Studies Education Research, 11(1), 21-41. Retrieved from https://jsser.org/index.php/jsser/article/view/1771

McQuail, D., \& Windahl, S. (1993). Communication models for the study of mass communication. London: Longman.

Mezza-García, N., Froese, T., \& Fernández, N. (2014) Reflections on the complexity of ancient social heterarchies: Toward new models of social self-organization in pre-Hispanic Colombia. Journal of Sociocybernetics, 12, 3-17.

Mouzelis, N. (1994). Nationalism in late development. Athens: Themelio.

Niora, N. (2009). The "Paschaliogiorta" in a Macedonian community: Lived experience or dramatic discipline? Unpublished Master's thesis. Athens: Department of Physical Education and Sport Science, National and Kapodistrian University of Athens.

Nitsiakos, V. (1995). Place, locality and national identity. Ethnologia, 4, 93-106.

Ogurchov, PA (1983). Comparative-historical method. In The Great Soviet Encyclopedia (pp. 298299). Athens: Akadimos.

Panopoulou, K. (2001). The dance identity of the Vlachs of the prefecture of Serres. Unpublished Ph.D. thesis. Serres: Department of Physical Education and Sport Science, Aristotle University of Thessaloniki.

Papakostas, Ch. (2007). Dance-musical identity and otherness: The case of the Roma of Heraklion in the prefecture of Serres. Unpublished Ph.D. thesis. Thessaly: University of Thessaly.

Papataxiarchis, E., \& Paradellis, Th. (eds.) (1993). Anthropology and the past: Contributions to the social history of modern Greece. Athens: Alexandria.

Parker, J. (2019). Second language learning and cultural identity. Journal of Curriculum Studies Research, 1(1), 33-42. https://doi.org/10.46303/jcsr.01.01.3

Paschalidis, G. (2000). Cultural identity as a right and as a threat: The dialectic of identity and the ambivalence of criticism. In Ch. Konstantopoulou, L. Maratou-Alibrandi, D. Germanos, \& Th. Oikonomou (eds.), "We" and "Others". Reference to Trends and Symbols (pp. 73-83). Athens: Typothito. 
Ritter, M. (2020). Civility and Shared Fate: Social Studies Teaching as Teaching for Belonging. Journal of Curriculum Studies Research, 2(1), 1-15. https://doi.org/10.46303/jcsr.02.01.1

Robbins, C., Bishop, J., \& Tarman, B. (2019). Against Reactionary Populism: Opening a Needed Conversation in Education. Journal of Culture and Values in Education,2(3), i-vi. https://doi.org/10.46303/jcve.03.02.ed

Sarakatsianou, Z. (2011). Ethnic groups and dance practices in Stenimachos, Imathia, Macedonia: The custom of St. Tryphon as an indicator of local cultural identity. Unpublished Master's thesis. Athens: Department of Physical Education and Sport Science, National and Kapodistrian University of Athens.

Scott, B. (2009). The role of higher education in understanding and achieving sustainable development: Lessons from sociocybernetics. Journal of Sociocybernetics, 7, 9-26.

Simmons, R. W., Smith, K., Erez, E.J., Burke P., \& Pozos. R. E. (1998). Balance retraining in a hemiparetic patient using center of gravity biofeedback: A single-case study. Perceptual and Motor Skills, 87, 603-609.

Sklar, D. (1991). On dance ethnography. CORD Dance Research Journal, 23(1), 6-10.

Smith, A. D. (1986). The ethnic origins of nations. Oxford: Blackwell.

Spanos, D. (2016). 'Synorata kai chariasia': Songs and dances from the circle of time and the circle of life. Sofiko Didymoteicho: Sofikou Women's Club.

Stets, J. E. (1995). Modelling control in relationships. Journal of Marriage and the Family, 57, 489-501.

Stocking, G. (1992). The ethnographer's magic and other essays in the history of Anthropology. Madison: The University of Wisconsin Press.

Stokes, P. (2006). Identity: articulating cybernetics and sociology. Kybernetes, 35(1/2), 124- 147.

Stokes, P. (2007). From management science to sociology: Cybernetics, finalization and the possibility of a social science. Kybernetes, 36(3/4), 420-436.

Thompson, P. (2002). Voices from the past: Oral history. Athens: Plethron.

Tonkin, E., McDonald, M., \& Chapman, M. (Eds.). (1989). History and ethnicity. London \& New York: Routledge.

Tsimpiridou, F. (1994). Space: Structures and representations. Anthropological proposal for reading the space in the Pomak villages of the prefecture of Rodopi. Ethnologia, 3, 5-30.

Tsitselikis, K. (1999). Addressing minority languages in Greece and the European legal environment on the eve of the 21st century. In the A. Christidis (eds.), Proceedings of an international conference, 'Strong' and 'weak' languages in the EU aspects of linguistic hegemony (vol. 2, pp. 785-793). Thessaloniki: Center for Greek Language.

Tsoukalas, K. (1996). The Greek national identity in a united Europe and the changing world order. In K. Tsoukalas (eds.) Journey to the word and history: Texts 1969-1996 (pp. 267-290). Athens: Plethron.

Tsouraki, M. (2013). Hegemony and cultural domination: The European dances of the bourgeoisie on the island of Zakynthos. Unpublished Master's Thesis. Athens: Department of Physical Education and Sport Science, National and Kapodistrian University of Athens.

Turner, V. (1967). The forest of symbols: Aspects of Ndembu ritual. Ithaca, London: Cornelee University.

Turner, V. (1969). The ritual process: Structure and anti-structure. New York, NY: Aldine de Gruyter.

Tyrovola, V. (2001). The Greek dance: A different approach. Athens: Gutenberg. 
Van Overschelde, J., \& Piatt, A. (2020). U.S. Every Student Succeeds Act: Negative Impacts on Teaching Out-of-Field. Research in Educational Policy and Management, 2(1), 1-22. https://doi.org/10.46303/repam.02.01.1

Ventura, L. (1993). Interpretive schemes of "national decline" in history textbooks (1922-1928). Diavazo, 332, 59-63.

Vrizas, K. (2005). Global communication: Political Identities. Athens: Gutenberg.

Watzlawick, P., Beavin, J. H., \& Jackson, D. D. (1967). Pragmatics of human communication: A study of interactional patterns, pathologies, and paradoxes. New York, NY: Norton. 